\title{
21. \\ POLITIČKI I KNJIŽEVNI NESPORAZUM \\ U PARADIGMI ODNOSA IZMEĐU \\ RIJEČI I STVARI
}

\section{Ivana Latković}

UDK: 821.163.6-3"195“

Izvorni znanstveni članak

Sažetak: Oslanjajući se na esej Jacquesa Rancièrea Književni nesporazum, u radu se na primjerima proznih ostvarenja - prije svega slovenske književnosti pedesetih godina, kao i na temelju književnopovijesnih konstrukata poslijeratnog razdoblja - pokušava pobliže odrediti načini oprisutnjenja krize i razgradnje staroga reprezentacijskog poretka proizašlog iz socijalističke stvarnosti i njihova prijelaza u novi, oporbeno modernistički. Na temelju Rancièreova tumačenja prekomjernosti, viška značenja u odnosu između riječi i stvari te njegova korespondiranja s danim društvenim sistemom, kao i onodobnim književno-kritičkim očitovanjima, nastoje se prikazati modeli i strategije fikcionalnog manevriranja u odazivu na ideološku danost (prije svega u smjeru podr(a)žavanja učinka realnog i očuvanja staroga prikazivačkog režima, odnosno odmaka od referencijalnog), kao i možebitna autorska razumijevanja same institucije književnosti.

Ključne riječi: prikazivanje, ratna proza, književni nesporazum, Jacques Rancière, slovenska književnost

\footnotetext{
7 nak današnjeg života nije više jasnost, već opća i voljna nejasnost. Neodređenost i neizražajnost nisu samo prirodni pratitelji života, već suštinski i svjesni orijentir čovje$\triangle$ čanstva koje je izgubilo herojski osjećaj. Što šira i mnogobrojnija postaje civilizacija, to su anonimnije njezine silnice. Zbog toga nejasnost ne predstavlja tek neku psihološku, već opću društvenu kategoriju. Društveno življenje na taj je način vrsta maskiranih koristi koje se na podlozi slobodne utakmice vitalnih sila bore za duhovnu premoć.
}

Riječi su to Edvarda Kocbeka iz njegova eseja Premišljevanje o Španiji objavljenog u Domu in svetu 1937./1938. godine, teksta koji je, u vrijeme kada je objavljen, izazvao žustru polemiku u slovenskim ne samo kulturnim krugovima, već i puno šire te susljedno tome uzrokovao jednu od većih kriza revije u kojoj je objavljen, a koja je kroz niz desetljeća (1888.-1944.) svoga izlaženja predstavljala jednog od glavnih glasnika i promotora slovenske katoličke inteligencije. ${ }^{1}$ Ne ulazeći ovdje detaljnije u političke reperkusije koje je taj tekst izazvao - naime, Kocbek je u njemu prilično jednoznačno španjolsku ljevicu ocijenio 
kao etički čistu, dok je katoličku stranu prozvao za fašističke namjere i time prizvao tada neželjene analogije na tadašnju slovensku situaciju - navedeni pasus iz Kocbekova eseja nedvojbeno pokazuje jedan u nizu tada učestalih pokušaja da se opažaji nemile stvarnosti koja je na pomolu nastoje opisati i razjasniti. Međutim, ova Kocbekova dijagnoza stvarnosti paradoksalno, ujedno i znakovito, kao svoju temeljnu objasnidbenu kategoriju uvodi upravo pojam nejasnosti. Kao vodećem intelektualcu svoga vremena, teško da bismo Kocbeku mogli pripisati jezičnu manjkavost ili spoznajnu nedovršenost vlastite misli, ili pak u tome vidjeti još jedan pretenciozan intelektualistički pokušaj zamućivanja smisla stvarnosti, već upravo suprotno, u tim bismo riječima možda mogli pronaći onu definiciju vremena blisko podudarnu s mislima Jacquesa Rancièrea koji pokušavajući rastumačiti uvijek aktualnu, pa i uznemirujuću sponu između dviju sfera javnog djelovanja, one političke s jedne i književne s druge strane, uvodi kategoriju nesporazuma, jednako začuđujuću kategoriju promišljanja, i u prvi mah za čitatelja s istim dojmom tendencije, zapravo, nerazjašnjavanja. ${ }^{2}$

Unatoč različitim pobudama, ciljevima, pa i naravi Kocbekova i Rancièreova teksta, njihovo dovođenje u vezu može se učiniti itekako plodotvornim u pokušaju mogućeg razjašnjavanja simptoma krize, a potom i načela razgradnje staroga reprezentacijskog poretka proizaš$\log$ iz krute socijalističke stvarnosti i njegova prijelaza u novi, onaj oporbeno modernistički, i to uglavnom u predstavljalačkim režimima ratne stvarnosti. No, prije same eksplikacije Rancièreove teze, nekoliko riječi o širem kontekstualnom okviru i pobudama ovoga izlaganja.

Gledajući književnopovijesne konstrukte ratnog razdoblja slovenske književnosti, ali i ne samo nje, kao i analitička nastojanja književnih ostvarenja koja ga tematski i vremenski obuhvaćaju, a koja su nastala u kasnijim desetljećima, vidljivo je kako su oni nerijetko impregnirani uglavnom grubo simplificiranom dihotomnom razdiobom. Nju s jedne strane čine ona književna ostvarenja koja kao ideološki i politički motivirani fenomeni slijede realističke režime predstavljanja, odražavajući socijalističku ratnu i poslijeratnu stvarnost, te s druge pak strane ona koja su po svojoj provenijenciji njoj oprečna, koja su građanskog naboja, modernističkog ustroja i kapitalističkog, zapadnjačkog usmjerenja. Takve se binarne projekcije razdoblja o kojemu je riječ u novije vrijeme sve više relativiziraju. Spomenimo, primjerice, knjigu Susan Buck-Marss Svijet snova i katastrofa ${ }^{3}$ u kojoj je iznesena teza kako je historijski eksperiment socijalizma, zapravo, duboko ukorijenjen u zapadnu tradiciju modernizacije te kako su kulturna događanja u suprotstavljenim političkim režimima 20. stoljeća (kapitalističkom i socijalističkom) varijacije jednog, istog motiva utopijskog sna o tome da industrijska modernost može usrećiti mase i da će na koncu to i učiniti. Ne ulazeći sada u autoričinu eksplikaciju navedene teze u širem političkom i ideološkom kontekstu, valja istaknuti kako ovdje nije cilj relativizirati ili čak poništiti razliku između dvaju reprezentacijskih režima ratne stvarnosti, jer to, dakako, nije moguće, već preispitati njihov odnos i možebitne korelacije, kao i analogije s društvenim i političkim sustavom unutar kojeg nastaju. Upravo na tragu toga, Jacques Rancière u svojoj knjizi Raspodjela osjetilnog - estetika i politika razlikuje tri režima umjetnosti u zapadnoj tradiciji, od kojih se dva odnose na ovu problematiku. Prvi naziva poetički ili reprezentacijski režim i on umjetnost identificira po mimetičkom principu. Mimezis, za Rancièrea „nije zakon koji umjetnosti potčinjava sličnosti” već je on „prije svega, nabor

Jacques RANCIĖRE, „Književni nesporazum”, Politika književnosti, Novi Sad 2008., 36.-50.

Susan BUCK-MORSS, Dreamworld and Catastrophe - The passing of mass Utopia in East in West; navedeno prema prijevodu Svet snova i katastrofa - Nestanak masovne utopije na Istoku i Zapadu, Beograd 2005., xii, xiv. 
koji povezuje raspodjelu načina stvaranja i društvenih zanimanja koja umjetnosti čine vidljivima”, dakle, on nije „umjetnički postupak već jedan režim vidljivosti umjetnosti”. ${ }^{4} \mathrm{U}$ skladu s time, po Rancièreu reprezentacijska logika „ulazi u analogiju s cijelom jednom hijerarhijskom vizijom zajednice". ${ }^{5}$ Nasuprot tome stoji takozvani estetski režim „koji točno identificira pojedinu umjetnost te ju razvrgne od svakog specifičnog pravila, od svake hijerarhije tema, vrsti i umjetnosti (...) on to čini uništavajući mimetičke granice”. I nadalje, „(o)n potvrđuje apsolutnu jedinstvenost umjetnosti te istodobno uništava sve pragmatičke kriterije te jedinstvenosti” $\mathrm{i}$,utemeljuje autonomiju umjetnosti i identitet njezinih oblika”. Shodno tome Rancière zaključuje kako je estetski režim umjetnosti „pravo ime onoga što zbrkano opisuje naziv modernost”. ${ }^{6}$ Međutim, navedene režime umjetnosti nikako ne valja pojednostavljenom analogijom dovesti do razlikovanja između reprezentacijskih praksi modernog i realističkog romana, jer potonji, kako ističe sam Rancière, prije svega znači „okretanje hijerarhija reprezentacije (prvenstvo narativnog pred deskriptivnim ili hijerarhije tema) i prihvaćanje svojevrsne fragmentirane ili pomaknute fokalizacije koju nameće surova prisutnost na štetu racionalne montaže povijesti”. Ono što pak počiva u srži ova Rancièreova razlikovanja, a čime bi se mogli problematizirati i reprezentacijski protokoli ratnih zbivanja u fikcionalnim tekstovima, odnosi se na svojevrsnu razgradnju poetske hijerarhije svojstvene klasičnom, odnosno poetičkom redu predstavljanja stvari koje odlikuje suglasje između stila, teme i lika. ${ }^{8}$ Princip tog prevrata Rancière smješta na početak 19. stoljeća kada se već u predgovoru knjige Lyrical Ballads Wordswortha i Coleridgea prepoznaje poruka koja ne samo da govori da više nema ni lijepih ni ružnih tema, već još više, ocrtava se ravnodušnost u samoj kompoziciji radnji i izražavanju misli i osjećaja, koji su bili suština poetske kompozicije. Tekstura djela je u njegovom stilu, nastavlja Rancière, i to stilu kao apsolutnom načinu sagledavanja stvari. Opisani princip do krajnosti je doveden s Flaubertom. ${ }^{9}$ Upravo na primjeru toga autora, odnosno njegovih kritičara Rancière pokazuje suodnos politike i književnosti. Naime, Sartre je u svom čuvenom eseju Što je književnost Flauberta optužio za „predvodnika aristokratskog napada na demokratsku prirodu prozaičnog jezika", ${ }^{10}$ od nosno za stjegonošu čiste književnosti koja nije htjela prihvatiti buržoaski način razmišljanja i koja je sanjala o novoj aristokraciji, pa su se riječi nastojale očistiti od komunikativne upotrebe kako se ne bi mogle koristiti kao sredstvo političkih debata i društvene borbe. S druge pak strane, u Flaubertovom brisanju hijerarhije između uzvišenih i niskih tema, između naracije i deskripcije, između ljudi i stvari, njegovi su suvremenici vidjeli drugi politički sindrom, onaj demokratski, jer je u propadanju svih poetskih hijerarhija prepoznato rušenje i jednog poretka svijeta - apsolutizacija stila bila je književni recept za demokratski princip

4 Jacques RANCIÈRE, „Raspodjela osjetilnog - estetika i politika”, Up \& underground: art dossier, 7/2006., 9/10. (http://www.google.hr/url?sa=t\&rct=j\&q=\&esrc=s\&frm =1\&source=web\&cd=2\&ved=0CDEQFjAB\&url=http\%3 A\%2F\%2Fwww.up-underground.com\%2Fpdf\%2F0910\%2F0910_jacques_ranciere-raspodjela_osjetilnog.pdf\&ei =oufUNOFD6rf4QSznYHABg\&usg=AFQjCNE31Re2_oKgqQIW7JPlmGp1W0_uCw). (20. 8. 2012.)

Isto.

Isto.

Isto.

Hijerarhijska podjela fikcije ovdje je visokim žanrovima dodijelila uzvišene radnje i likove, dok su niski žanrovi bili posvećeni pričama običnih ljudi.

J. RANCIËRE, Politika književnosti, 13.-14.

${ }_{10}$ Isto, 11. 
jednakosti koja je ukazivala na propast stare nadmoći djelovanja nad životom, na socijalnu i političku promociju običnih ljudi. ${ }^{11}$

$\mathrm{Na}$ ovaj način sažete i interpretirane teze Jacquesa Rancièrea mogle bi se preispitati i na reprezentacijskim praksama ratne stvarnosti. Gledajući prozne tekstove ratne tematike od početka njihova pojavljivanja do kraja sedamdesetih godina kada taj vid prozne produkcije pomalo posustaje i gubi svoje čitateljstvo, prijelomu točku nedvojbeno predstavlja zbirka novela Strah i hrabrost Edvarda Kocbeka iz 1951. godine koja je u trenutku kada je objavljena izazvala veliku buru i negodovanje u javnosti, te na koncu autora natjerala i na prisilno umirovljenje. Među brojnim reakcijama koje je zbirka izazvala ističe se ona Josipa Vidmara objavljena 1952. godine u reviji Novi svet. U njoj kritičar nemalo negoduje zbog Kocbekova radikalna zaokreta u prikazivanju ratnih događanja i zbirku decidirano negativno ocjenjuje. Sažeto, zamjera mu da je umjesto junaka uprizorio očajnike koji čak nisu ni jasno oblikovani, već su tek nekakve psihičke izmaglice bez jasnih karakternih crta. Uz to, oni još razotkrivaju i svoju potpunu nesvrhovitost, zaključuje Vidmar iz sljedećih riječi iz Kocbekove zbirke: „Moja mi unutrašnjost snažno govori da moram ostati ljudski neovisan i slobodan, a ne samo povijesno uporaban i koristan”. ${ }^{12}$ Ovdje Vidmar iščitava negativno vrednovanje oslobodilačke borbe jer je ona podređena osobnoj slobodi, što na koncu Kocbeka dovodi do apsurdne misli o povijesti proizašle iz zastupanja moralne anarhije (potonje Vidmar izvodi iz pripovjedačevih preispitivanja granica između dobra i zla u ratnim zbivanjima). Na koncu, sve to, smatra Vidmar, posljedica je Kocbekova pokušaja da prikaže psihu kršćana u ratu, ali to mu ne uspijeva, jer je njegov svjetonazor zadojen nekritičkim preuzimanjem pomodne spiritualističke misaonosti iz suvremene francuske literature, personalizma i egistencijalizma. Zbog svega toga, Vidmar smatra kako je Kocbekova slika oslobodilačke borbe „bezumno nepravedna, nepijetetna i neljudska”. ${ }^{13} \mathrm{Njezin}$ bogat i bujan stil pretvara se u magloviti hiperbolizam i mistifikaciju dubokoumnih riječi. $\mathrm{Na}$ koncu, Vidmar poentira mišlju da je Kocbek oskvrnuo ne samo osjećaje koje moramo gajiti prema našoj oslobodilačkoj borbi, već i čovječanstvo, svijest i volju svijeta koji se bori za slobodu, za napredak, oskvrnuo je ono najviše u čovječanstvu što ga je donijelo iz tame pradavnih vremena u sadašnjost. ${ }^{14}$

U pregrštu srazova između književnika koji su se nastojali izmaknuti shematiziranom prikazivanju ratne stvarnosti i njihovih kritičara, ovaj između Kocbeka i Vidmara čini se višestruko simptomatičan s obzirom na idejnu i ideološku platformu vremena u kojem nastaje. Obojica autora kao pripadnici tadašnjeg kulturnog, ali i političkog establishmenta, te kao vrhunski intelektualci svoga vremena, imali su prilično razrađen i dorađen sustav estetskih vrijednosti koji su s više ili manje dosljednosti provodili, ali i, ne manje važno, visoku pozicioniranost u tadašnjoj slovenskoj politici. U ideološkom smislu, njihove su startne pozicije oprečne, vezuju se za pripadnost dvama glavnim i još od druge polovice 19. stoljeća suprotstavljenim taborima, Kocbek katoličkom, Vidmar slobodoumnom, liberalnom. Sasvim sažeto mogli bismo reći kako je Kocbek svoje napredno katoličanstvo ljevičarskog usmjerenja jasnije zastupao i provodio, dok se Vidmarevo slobodoumlje u njegovim književno-kritičkim istupima pod teretom pristajanja uz komunističku revoluciju uvelike po-

\footnotetext{
Isto, 11.-15.

12 Josip VIDMAR, „Kritika - Edvard Kocbek: Strah in pogum”, Novi svet, 7/1952., br. 1, 80.

13 Isto, 85 .

14 Isto, 84.
} 
litički i ideološki kontaminiralo. Unatoč različitosti polaznih ideologija, njihov susret ipak se desio, i to uime viših, sveopćih ciljeva, a u vidu djelovanja u Osvobodilnoj fronti gdje su obojica obnašali istaknute funkcije. Možda upravo zbog toga zajedničkog udjela u iskustvu ratne stvarnosti Vidmar biva dodatno razočaran i ojađen Kocbekovim opisivanjem oslobodilačke borbe. U njegovu antagonizmu naspram načina prikazivanja ratnih događanja posebno mjesto zauzima tobožnja mistifikacija prikazanog (ona je za Vidmara ponegdje čak i perverzna!) i, kako se daje naslutiti iz sume kritičarevih stavova, time je heretički zamućen sveopći smisao i cilj oslobodilačke borbe. Jasno je kako je ovdje Vidmarev horizont očekivanja uvelike promašen, jer počiva na potpuno drugačijim pretpostavkama fikcionalnog prikazivanja rata od onih koje realizira Kocbek u svojim novelama. Taj bismo promašaj sažeto mogli odrediti kao odstupanje od tada ustaljena reda u odnosu između riječi i stvari, jer prikazano izmiče biti tek vjernom kopijom stvarnosti, naglašavajući pri tome da je ono uvijek već personalna interpretacija. Ona za sobom uvijek ostavlja svojevrsni višak smisla i značenja koji se nikada u potpunosti ne mogu dohvatiti i stabilizirati. Jaz nastaje u činjenici da u Strahu i hrabrosti nema reprezentativnog junaka koji bi bio nositelj velike ideje, nema jednoznačnog određivanja što je dobro, a što zlo, posljedično tome, moralne, kao i sve druge vrijednosti dovedene su u pitanje, pa nema optimizma i slavljenja budućnosti, ukratko, suviše analize u tako žuđenoj sintezi. Rancièreovim pak riječima, narušena je ovdje poetska hijerarhija koja je pandan čvrsto uređenoga političkog sustava koji ne dopušta dijalog i meditacije, već iziskuje homogenu i monološku svijest te istu takvu ovjeru vlastita postojanja. On će uvijek iznova tražiti jednoznačnu potvrdu ideološkog okvira unutar kojeg nastaje pa se demokratsko preispitivanje koje stvara svojevrsni značenjski nepoželjan višak, pokušava u temeljima zatrti i/ili poništiti. U tom smislu Kocbekovo uprizorenje oslobodilačke borbe u svom gomilanju značenja, kako kaže Rancière, urušava sistem razlika koji je socijalnoj hijerarhiji dozvoljavao da bude predstavljena, jer napušta logiku radnji koje navodno slijede razumne ciljeve da bi se okrenulo svijetu značenja skrivenih pod plaštom prividne banalnosti. ${ }^{15}$ Time ono narušava harmoničnu cjelinu. Upravo potonjeg tiče se književni nesporazum o kojem govori Rancière. Naime, on nije posljedica jezične dvosmislenosti, njegova srž nije hermeneutička, već se on odnosi na paradigmu odnosa između riječi i stvari, odnosno prekomjernosti broja tijela i broja riječi, značenja u odnosu na pretpostavljenu harmoniju između njih. ${ }^{16}$ I dok politika radi na cjelini, književnost ide u suprotnom smjeru i uspostavlja neke druge odnose među značenjima i stanjima stvari, ona individualizirajući osmišljava ličnosti na osnovi mrlja, pa te mrlje pretvara u metaforičke elemente. ${ }^{17} \mathrm{Na}$ koncu, Kocbekova „neposlušnost” počiva upravo na metaforičnosti koja se opire tada tako željenoj formulaičnosti govora, koju je propagirala i provodila sama politika, a pod okriljem socrealističke paradigme potom prisvojila i književnost.

Kocbekov ekscesni modernizam u to doba, ranih pedesetih nije dobio svoga sljedbenika, uz više ili manje odstupanja ratna je proza slijedila shematizirano pojednostavljenu i mitologiziranu sliku stvarnosti. Doduše, pokušaji njezina preslagivanja vidljivi su primjerice kod C. Kosmača (u noveli Balada o trubi i oblaku te u romanu Proljetni dan), ili oni diskretniji u vidu psihologizacije prikazanog kao što je slučaj kod J. Kozaka ili pak na ponešto dru-

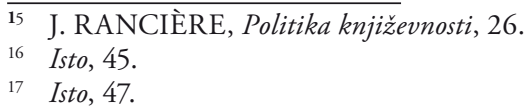


gačiji način realizirane su te tendencije kod autora starije generacije, primjerice Prežihova Voranca ili M. Kranjca. Uz to, valja spomenuti i tršćanske autore, A. Rebulu i B. Pahora koji su spomenutu sliku stvarnosti nastojali subjektivizirati u različitim reprezentacijskim modusima. Ipak, u većini slučajeva njihovo potencijalno oporbenjaštvo bilo je više deklarativnog tipa, dovoljno konzervativno da bi se preduhitrile dovitljive optužbe vladajućih.

Znakovito, prvi uvjerljivo autonoman pokušaj oslobađanja prikaza od ideološkog balasta (barem od onog socijalističkog/realističkog) dogodio se sedamdesetih godina, i to iz pera bivšeg partizana, eufemistički rečeno, nikada omiljenog među onima na vlasti, Vitomila Zupana koji 1975. godine objavljuje roman Menuet za gitaru. Vrijeme u kojemu nastaje ovaj ratni roman u slovenskoj je književnosti obilježeno naglašenim interesom za teme iz prošlosti, tada se u modusu sjećanja - ispovijedanja javljaju brojni prozni tekstovi koji dijalogiziraju ili polemiziraju s nedavnom prošlošću. Riječima M. Juvana, karakteristična je za to vrijeme naglašena prisutnost dnevničke i memoarske proze u kojoj su autori koji su proživjeli Drugi svjetski rat javnosti razotkrivali do tada u društvu tabuizirane i bolne teme vezane za traumatičnu „veliku priču” Drugoga svjetskog rata: bratoubilačke ideološke sukobe u NOB-u, informbiroovski raskol u Partiji, montirane političke procese i represiju nad „unutrašnjim neprijateljima” nakon 1948. itd. Žrtvenost osobnog udjela u povijesti ovi će autori posredovati kroz infantilnu pripovjednu perspektivu ili pomoću asocijativnosti i fragmentiranosti sjećanja, toka svijesti ili poliloga različitih pogleda, kao i pomoću montaže fakcije i fikcije. Ti tekstovi, zaključuje Juvan, bili su, među ostalim, i alegorija ili oružje s kojim se je takozvana kritička inteligencija hvatala u koštac s vladajućom ideologijom i političkim garniturama. ${ }^{18}$

Zupanov doprinos ovdje je nedvojbeno velik. Menuet za gitaru doista jest oporbeni tekst na svim svojim razinama: od samog konstituiranja priče koja je razlomljena na dvije vremenski odijeljene fabularne linije (prva obuhvaća ratna zbivanja 1942./43. u Sloveniji, druga se odvija tridesetak godina kasnije u španjolskom turističkom gradiću), pri čemu druga preispituje i relativizira prvu, preko pripovjednog okvira koji je formuliran kao preispisivanje tobožnjeg dnevnika nekadašnjeg partizana, do uprizorenja glavnog lika, „brbljavog liberala”, intelektualca čija se postojanost uvijek iznova potvrđuje u zasebnosti i izmicanju aktualnim ideološkim obrascima i nadzoru doktrine, kao i zbog činjenice da se propitivanjem odnosa između dobra i zla, između žrtve i agresora, monolitni koncept pamćenja i oskudni protok sjećanja postupno raspadaju. Pridodamo li tome sav popratni modernistički instrumentarij u koji je prikaz uronjen, ali i ključna mjesta (anti)junakove misaonosti - „Cijela povijest govori o borbama za slobodu, za oslobođenje, za demokraciju, za jednakost, bratstvo, za pravdu! A tko piše povijest? No, tko ima tiskare? Tko drži cenzurne škare? Ideje su industrijska sirovina vladajućih klasa." ${ }^{19}$ - jasno je kako je nekadašnje slavljenje i mitologiziranje oslobodilačke borbe u reprezentacijskom modusu tobožnje vjerne kopije stvarnosti radikalno nadiđena koncepcija. I još više, Zupanov roman glasno je zalupio vrata hijerarhiziranju stvarnosti u pojmovima ideologije, povijesti i pojedinca. Stvorio je neposluh u strukturi, i to pripisivanjem viška riječi i značenja, viška koji ona svojom postojećom konstitucijom ne može apsorbirati.

\footnotetext{
8 Marko JUVAN, „Postmodernizem in 'mlada slovenska proza”, Jezik in slovstvo, 34/1988., br. 3, 49.

19 Vitomil ZUPAN, Menuet za gitaru, Zagreb 1985., 379.
} 
Kao što je već u nekoliko navrata bilo spomenuto, Kocbekove novele i Zupanov roman nisu jedini primjeri prikazivačkih novina ratne tematike, ali su dvije ključne točke u njezinu dijakronijskom sagledavanju i unatoč tome što su vremenski udaljeni gotovo četvrt stoljeća, njihova zajednička priroda počiva u, Rancièreovim riječima, „demokraciji lutajućeg pisma”, ${ }^{20}$ odnosno, njihova demokratska logika pisma bez učitelja i odredišta (barem ne eksplicitnog) potvrđuje sposobnost da je svatko u mogućnosti domoći se riječi, značenja, pa tako oni otkrivaju $\mathrm{i}$ „hermeneutiku društvenog tijela”. ${ }^{21} \mathrm{U}$ vezi s time, socrealistička paradigma kao institucionalni model puno je češće u svoje redove propuštala umjerenije i diskretnije oporbene podvige pa su utoliko više „udari” Kocbeka i Zupana simptomatičniji, jer, među ostalim, ukazuju i na svojevrsnu strategiju političkog i kulturnog establishmenta te njihovu možebitnu manipulaciju javnim diskursom. Naime, pedesetih godina, nakon prekida veza sa SSSR-om i stješnjenja u nekakvom međublokovskom stanju, politika jest izravno ili neizravno preispitivala nove sadržaje u potrazi za svojim legitimitetom, dok su s druge strane, sedamdesetih godina, kada su vjerojatno kulminirala Titova idejna prekrojavanja komunističkog režima, a zapadnjačka progresivna modernost poprimila maha, ovakvi književni istupi bili potvrda tobožnjeg liberalizma, ali i mjesto ovjerovljavanja političke pripovijesti. Možda je to isuviše simplificirano tumačena kauzalnost između političke i književne sfere, posebice uzmemo li u obzir svjedočenja književnika - intelektualca aktivnih u vrijeme Drugoga svjetskog rata. Primjerice, JeanPaul Sartre u svome eseju Piščeva situacija 1947 slikovito navodi da su u to vrijeme svi ljudi „sličili na Charlesa Bovaryja koji kad poslije smrti svoje žene nađe pisma njezinih ljubavnika, vidi kako se odjednom za njim ruši dvadeset godina već proživljene bračne sreće", ${ }^{22}$ pa u tom vremenu brutalnog vraćanja u historiju, kaže Sartre, „bili smo primorani stvarati literaturu od historičnosti" 23 te nastavlja, jer

nismo htjeli našoj publici omogućiti da uživa u svojoj superiornosti nad jednim mrtvim svijetom; željeli smo je uhvatiti za gušu: da svaki lik bude zamka, da čitatelj u nju bude uhvaćen i da bude bacan iz jedne savjesti u drugu, kao iz jednog apsolutnog i neizlječivog svijeta u drugi isto tako apsolutan svijet, da bude nesiguran samom nesigurnošću junaka, nemiran njihovim nemirom, savladan njihovom sadašnjošću, pritisnut težinom njihove budućnosti, opkoljen njihovim zapažnjima i njihovim osjećajima kao visokim i neosvojivim liticama, da na koncu osjeti kako svaka njihova ćud, svaki pokret njihovog duha obuhvaća čitavo čovječanstvo. ${ }^{24}$

Kao da su upravo takvu sliku svijeta nastojali stvoriti i Kocbek i Zupan, pri tome sa sviješću da društvu daju, kako Sartre u jednom drugom eseju kaže, „nesretnu savjest”:

(a)ko društvo vidi sebe, a pogotovo ako vidi da je viđeno, u samoj toj činjenici sadržano je osporavanje utvrđenih vrijednosti i režima: pisac mu pruža njegovu sliku i poziva ga da je prihvati ili da se izmijeni. A društvo se u svakom slučaju mijenja; ono gubi ravnotežu koje mu je davalo neznanje. ${ }^{25}$

Iako izvorno u poznatom Sartreovom konceptu angažirane književnosti nije mišljeno, to gubljenje ravnoteže kroz „nesretnu savjest” može imati i dalekosežnije posljedice u stalno prisutnoj destabilizaciji institucije same književnosti, pa u skladu s Rancièreom, i njezina

\footnotetext{
J. RANCIÈRE, Politika književnosti, 21.

Isto, 26.

Žan-Pol SARTR, Šta je književnost, Beograd 1984., 137.

Isto, 139.

Isto, 145.

Isto, 61.
} 
udjela u preraspodjeli prostora i vremena, kao i utjecaja na odnos između drugih praksi. Drugim riječima, nisu li Kocbekov i Zupanov istup u svojim „prekoračenjima” zapravo podrivalački čimbenik postojeće književne institucije, njezinih normi i konvencija, kao i odnosa između stvarnosti i književnosti te potonjoj pripisivanih funkcija? $\mathrm{Na}$ tragu sličnih premisa, a u potrazi istog odgovora, Ivana Žužul pristupa u analizi Šegedinova romana Djeca božja koji, kao što je poznato, u hrvatskoj književnosti nosi „teret” raskida $s$ tada prevladavajućom socrealističkom poetikom i njezinom zrcalnom reprezentacijom stvarnosti. U Djeci božjoj, naime, autorica prepoznaje već u samom tekstu naviještenu ideju „da se mjesto književnosti, ma koliko zadano poetičkim i konvencijama i institucijama, nekom vrstom viška njima uvijek opire” jer provociranjem i onečišćenjem jasnih i isključivih granica što ih je književnosti osiguravala ideologizirana estetička struja, Šegedin dovodi u pitanje sam institucionalni status književnosti. ${ }^{26}$ I nadalje, oslanjajući se na J. Derridu, autorica ističe proturječnu institucionalnu narav prostora književnosti ne samo kao prostora institucionalizirane fikcije, već i fiktivne institucije. U skladu s time, sažmemo li autoričine zaključke i pridodamo li svoje, mogli bismo reći kako Kocbekov, Zupanov pa i Šegedinov tekst u skladu sa svojim, Rancièreovim riječima, estetskim režimom, njegovom reintrepretacijom onoga što ili tko čini umjetnost, ${ }^{27}$ u svome prekoračenju značenja pripisanog danoj stvarnosti, u neproporcionalnosti riječi i stvari, potvrđuju neodredivost kao nužan uvjet nastanka i opstanka književnosti koje će u slučajevima poput Vidmareva tumačenja Kocbeka ili Gamulinova čitanja Šegedina, uvijek i neprestano izmicati.

Zbog izostanka oporbenjaštva šegedinsko-krležijanskog tipa, slovenska poslijeratna proza velik dio svoga emancipacijskog angažmana od tvrdokorne socrealističke poetike duguje upravo tekstovima ratne tematike, znakovito autora koji su bili sudionici opisanih zbivanja. Možda upravo zbog toga ti su se književni tekstovi, da parafraziram Rancièrea, u raskoraku između svojih nuđenih nad-značenja i pod-značenja udaljavali od služenja političkoj slozi, stvarajući pri tome sebi svojstvenu meta-politiku, dok su istovremeno njihovi autori nagoviještali onu, po Foucaultu, novu ulogu intelektualca koju ne čine njegovi podvizi da ispred svih ili negdje po strani izražava prigušene istine kolektivnog, već da se bori protiv oblika moći koji ga pretvaraju u objekt i instrument u sferi „znanja”, „istine”, „svijesti” i „diskursa”. ${ }^{28}$

26 Ivana ŽUŽUL, „Što je književnost?’ u Šegedinovu romanu Djeca božja”, Dani Petra Šegedina: Hrvatska književna tradicija i modernost u djelu Petra Šegedina. Zbornik radova, (ur. Dubravko Jelčić), Korčula 2010., 23.

27 Jacques RANCIÈRE, „Raspodjela osjetilnog - estetika i politika”.

28 Michel FOUCAULT - Gilles DELEUZE, „Intellectuals and Power: A Conversation between Michel Foucault and Gilles Deleuze" (http://libcom.org/library/intellectuals-power-aconversation-between-michel-foucault-and-gillesdeleuze). (28. 7. 2012.) 


\section{THE POLITICAL AND THE LITERARY MISUNDERSTANDING IN THE PARADIGM OF THE RELATIONSHIP BETWEEN THE WORD AND THINGS}

Using Rancière's dichotomy between the poetic and the aesthetic regime of art, and the author's own view of the literary misunderstanding, which is a result of an overabundance of meaning as opposed to the supposed harmony between words and things, the paper uses mostly examples from Slovenian wartime prose to show the ways in which the crisis and the dissolution of the old oppositional, representational order that had emerged from the rigid socialist reality are made present, as well as the ways in which they transform into the new, oppositional modernist representational order. Analysis shows that those texts, with their unreliable, incomplete subjects and wandering viewpoints which defy definition, as well as the "pollution" of reality with fiction in ways which break down the poetic hierarchy typical of the classical order of representation, confirm an affiliation with the aesthetical regime in art as understood by Rancière and his reinterpretation of who or what makes art. Accordingly, the subversion of ideologized aesthetic models and patterns implies a redefinition of the institution of literature itself. As a participant in the division between the visible and the invisible and a factor affecting the relationships between other social practices, literature reveals, again in Ranciere's terms, the "hermeneutics of the social body".

Keywords: representation, wartime prose, Jacques Rancière, Slovenian literature, literary misunderstanding

\section{$\cos$}

\section{Literatura}

Suzan BAK-MORS, Svet snova i katastrofa - Nestanak masovne utopije na Istoku i Zapadu, Beo$\operatorname{grad} 2005$.

Michel FOUCAULT - Gilles DELEUZE, „Intellectuals and Power: A Conversation between Michel Foucault and Gilles Deleuze" (http://libcom.org/library/intellectuals-power-aconversationbetween-michel-foucault-and-gilles-deleuze). (28. 7. 2012.)

Marko JUVAN, „Postmodernizem in 'mlada slovenska proza'”, Jezik in slovstvo 34/1988., br. 3, 49.-56.

Edvard KOCBEK, „Premišljevanje o Španiji”, Dom in svet, 50/1937.-1938., br. 1-2, 90.-105.

Jacques RANCIÈRE, Politika književnosti, Novi Sad 2008.

Jacques RANCIÈRE, „Raspodjela osjetilnog - estetika i politika”, Up \& underground: art dossier, 7/2006., br. 9-10 (http://www.google.hr/url?sa=t\&rct=j\&q=\&esrc=s\&frm=1\&s ource=web \&cd=2\&ved=0 CDEQFjAB\&url=http\%3A\%2F\%2Fwww.up-underground. com\%2Fpdf\%2F0910\%2F0910_jacques_ranciere-raspodjela_osjetilnog.pdf\&ei=ouflUNOF D6rf4QSznYHABg\&usg=AFQjCNE31Re2_oKgqQIW7JPlmGp1W0_uCw). (20. 8. 2012.)

Žan-Pol SARTR [Jean-Paul Sartre], Šta je književnost, Beograd 1984.

Josip VIDMAR, „Kritika - Edvard Kocbek: Strah in pogum”, Novi svet, 7/1952., br. 1, 78.-85. 
Vitomil ZUPAN, Menuet za gitaru, Zagreb 1985.

Ivana ŽUŽUL, „Što je književnost?’ u Šegedinovu romanu Djeca božja”, Dani Petra Šegedina: Hrvatska književna tradicija i modernost u djelu Petra Šegedina. Zbornik radova, (ur. Dubravko Jelčić), Korčula 2010., 21.-33. 